\title{
Induction of intercellular adhesion molecule 1 and class II histocompatibility antigens in colorectal tumour cells expressing activated
} ras oncogene

\author{
V Stoneman, A Morris
}

\begin{abstract}
Aims-To determine whether there is a correlation between activation of the ras oncogene and the induction of MHC class II antigens and intercellular adhesion molecule 1 (ICAM-1) by interferon- $\gamma$ (IFN- $\gamma$ ).

Methods-Expression of class II antigens, ICAM-1 and intracellular ras oncoprotein (p21) in established colorectal cell lines and short term cultures of primary colorectal tumour cells was determined by flow cytometry and mutation in the ras gene by sequencing of amplified segments of the gene.

Results-The cell lines showed a variation in their modulation of MHC class II antigens and ICAM-1, ranging from no induction to a 98-fold increase in class II antigen expression in the HT29 cell line. Previous work indicated that most tumours could not be induced to express class II antigens. Four of the five least inducible lines either contained mutant ras or highly expressed the oncoprotein. The four highly inducible cell lines all contained non-mutant ras. Of the 21 tumours studied in primary culture, 10 were inducible, one of which contained mutant ras. Of the remaining non-inducible tumours, four were mutant.

Conclusions-Correlations between ras activation and failure to respond to IFN- $\gamma$ could not be shown to be significant. Therefore, ras activation, and concomitant subversion of intracellular signalling pathways, is probably not the major determinant in failure to activate class II antigens and ICAM-1.

(f Clin Pathol: Mol Pathol 1995;48:M326-M332)
\end{abstract}

Keywords: Histocompatibility antigens, intercellular adhesion molecule 1 , ras.

Department of Biological Sciences, University of Warwick, Coventry CV4 7AL V Stoneman A Morris

Correspondence to: Dr A Morris.

Accepted for publication 26 September 1995
Inflammatory responses in tissues are often accompanied by augmentation of the expression of class II MHC antigens (HLA DR, $\mathrm{DP}$ and $\mathrm{DQ}$ ) and of intercellular adhesion molecule 1 (ICAM-1) by cells. This is particularly apparent in rejection of allografts (for example, kidney ${ }^{1}$ ) and in autoimmune disease (for example, inflammatory bowel disease ${ }^{2}$ ) and is ascribed to the production of cytokines, especially interferon- $\gamma($ IFN- $\gamma)$, by activated T cells.
Inflammatory responses occur in a proportion of patients with cancer, with infiltration by leucocytes and upregulation at least of HLA DR. T cells responding in an MHC restricted manner to self antigens expressed by the tumours have been identified, suggesting that in some instances these inflammatory responses may be specific immune responses (reviewed in ${ }^{3}$ ). There are some reports that a strong inflammatory response is indicative of a better prognosis (for example, in carcinoma of the larynx, ${ }^{4}$ breast, ${ }^{5}$ stomach, ${ }^{6}$ and colorectum ${ }^{7}$ ) and experimental data showing that expression of class II histocompatibility antigens by tumour cells influences their tumorigenicity. ${ }^{89}$ However, the extent of the inflammatory response in cancer is highly variable, with the degree of leucocytic infiltration ranging from virtually nil to very extensive, and the expression of class II antigens and ICAM-1 equally ranging from nil to very intense, with little correlation between the two. This variation may be related to differing capacities of tumour cells to respond to cytokines by upregulation of class II antigens and ICAM-1. We have demonstrated recently that tumour cells from most colorectal carcinomas which are negative for expression of $\mathrm{MHC}$ class II antigens and ICAM-1 are incapable of responding to IFN- $\gamma$ by upregulating these molecules. ${ }^{10}$ In this paper we seek to demonstrate that this failure of response may be related to the activation of the proto-oncogene $\mathrm{Ki}$-ras in the tumour cells, arguing that the subversion of intracellular signalling pathways resulting from such activation may disrupt cytokine responses.

The importance of the family of ras oncogenes is that it plays a central role in intracellular pathways, transducing growth factor signals from the cell membrane to the nucleus. The products of the ras oncogenes are small GTPases of $21 \mathrm{kDa}\left(\mathrm{p} 21^{\text {ras}}\right)$ whose function is to transmit the signal from activated growth factor receptors to the raf gene product and thence via a series of mitogen activated kinases (MAP kinases) to the nucleus, where transcription of a range of genes important in cellular proliferation is stimulated. ${ }^{11}$ Activation of ras by mutation or overexpression, or by subversion of other components of the pathway involving the ras gene product, results in stimulation of cell proliferation. In a number of human cancers there is activation of ras and in 
Table 1 Primers used for PCR amplification and sequencing

\begin{tabular}{ll}
\hline Primer identification & Primer sequence \\
\hline Codon 12 & 5' GGC CTG CTG AAA ATC ACT GA 3' \\
12.1B & 5' GTC CTG CAC CAG TAA TAT 3' \\
12.2B & \\
Codon 61 & \\
61.1B & 5' TTC CTA CAG GAA GCA AGT AG 3' \\
61.2B & 5' CAC AAA GAA AGC CCT CCC CA 3' \\
\hline
\end{tabular}

particular in about $40 \%$ of cases of colorectal carcinoma. ${ }^{12}$

It has become clear recently that cytokines, in particular IFN- $\gamma$, act via a signalling pathway not directly involving $\mathrm{p} 21^{\text {ras }}$. The principal component of the IFN- $\gamma$ signal transduction pathway is a protein with a molecular weight of $91 \mathrm{kDa}$ which is activated by phosphorylation as a consequence of IFN- $\gamma$ binding to its receptor. This protein then translocates to the nucleus where it activates transcription of a range of genes, ${ }^{13}$ including ICAM-1. In at least some cell types, however, IFN- $\gamma$ signalling may involve additional mechanisms, particularly activation of protein kinase C (PKC). ${ }^{14-16}$

There is evidence that the different signal transduction pathways are not independent: "cross talk" occurs, with the activation of growth factor signalling pathways affecting cytokine responses and vice versa. In fact, it has long been established that cytokines influence cellular proliferation both positively (interleukin 2 and many others) and negatively (the IFNs and transforming growth factor- $\beta$ ). Equally, cell functions thought largely to be under the control of cytokines may be influenced by growth factor signalling pathways-for example, both epidermal growth factor and transforming growth factor suppress induction of class II antigens. ${ }^{17}$ The retinoblastoma protein, important in the control of cell cycling, can influence class II induction by IFN- $\gamma{ }^{18}$ Activated ras can restore class II MHC antigen expression to class II negative B lymphoblastoid cells. ${ }^{19}$ Other oncogene products are known to influence class I MHC antigen expression-for example, $\mathrm{n}-m y c^{20}$ and adenovirus E1A protein. ${ }^{21}$ We have demonstrated that transfection of activated ras oncogenes into different murine fibroblasts results in both the transformation of the cells and changes in the expression of class II MHC antigens in response to IFN- $\gamma .{ }^{223}$

"Cross talk" may occur at the level of PKC, which is activated both by growth factors ${ }^{24}$ and by IFN- $\gamma^{14-16}$ and mediates at least some of the effects of both. Recently, it has argued that one of the crucial steps in the growth factor pathway, phosphorylation of the protein serine kinase raf (which initiates the MAP kinase cascade), requires activated PKC. ${ }^{25}$ Indeed, it has been shown that activation of MAP kinase can be achieved by IFN- $\gamma .{ }^{18}$ It is also clear that growth factors binding to their receptors can result in the phosphorylation of p91, indicating another possible means of "cross talk". ${ }^{1326-29}$

We therefore hypothesised that in human cancer cells in which growth factor signalling pathways are subverted, cytokine responses may also be defective. In order to investigate this, we have studied human tumour cells to determine whether subversion of the growth factor signal transduction pathway by ras activation influences the induction of expression of class II antigens and ICAM-1 in response to IFN- $\gamma$.

\section{Methods}

CELL LINES, CULTURE CONDITIONS AND

PREPARATION OF PRIMARY TUMOUR CELI SUSPENSIONS

The following established colorectal cell lines: Caco-2, Colo201, Colo205, HCT116, HT29, LoVo, LS180, SW1417, and SW1417, were supplied by the American Type Culture Collection (ATCC Rockville, Maryland, USA) or the European Collection of Animal Cell Culture (ECACC: Public Health Laboratory Service, Porton Down, UK). Cell culture medium used was RPMI (Gibco BRL) supplemented with "Myoclone Plus" fetal calf serum (Gibco BRL). All incubation and culture procedures were carried out at $37^{\circ} \mathrm{C}$ in $5 \% \mathrm{CO}_{2}$.

To prepare tumour cell suspensions, the excised tumours were dissected to remove obvious necrotic tissue and blood clots, and were then washed in cold RPMI medium to remove surface contamination. The tumours were then minced, followed by enzymatic disaggregation with $0.01 \mathrm{mg} / \mathrm{ml}$ hyaluronidase type V (Sigma, Poole, Dorset, UK), $0.02 \mathrm{mg} / \mathrm{ml}$ DNase type I (Boehringer Mannheim, Mannheim, Germany), $1 \mathrm{mg} / \mathrm{ml}$ collagenase A (Boehringer Mannheim) in RPMI medium containing $10 \%$ "Myoclone Plus" serum by gentle shaking at room temperature for about 15 hours. The disaggregated tissue was then washed, and the tumour cells separated from stromal cells by centrifugation on Percoll (Sigma) gradients. The tumour cell fraction was then used to prepare DNA.

INDUCTION OF CLASS II MHC ANTIGENS AND ICAM-1 IN CELL LINES AND

IMMUNOFLUORESCENCE

Cells were incubated for three days with $10^{2}$ units/ml of recombinant human IFN- $\gamma$, then trypsinised to prepare single cell suspensions, which were stained by direct immunofluorescence techniques using the monoclonal antibodies anti-ICAM-1 (CD54) clone $84 \mathrm{H} 10$ (fluorescein conjugate: Serotec MCA532, Oxford, UK) and L243 recognising a conserved HLA DR determinant (phycoerythrin conjugate: Becton Dickinson, Oxford, UK). The intensity of fluorescence was determined by flow cytometry using a Becton Dickinson FACStar.

\section{PCR AND SEQUENCING}

DNA was extracted by resuspending cell pellets in Hirt Buffer $(0.01 \mathrm{M}$ Tris/ $\mathrm{HCl}$ ( $\mathrm{pH} 7.4)$, $0.02 \mathrm{M}$ EDTA, $0.5 \%$ (w/v) sodium dodecyl sulphate) at $10^{6}$ cells $/ \mathrm{ml}$ and incubating with $100 \mathrm{~g} / \mathrm{ml}$ proteinase $\mathrm{K}$ (Boehringer Mannheim) overnight at $37^{\circ} \mathrm{C}$. The addition of a 1 in 30 volume of $3 \mathrm{M} \mathrm{NaCl}$ was followed by phenol/ 
chloroform extractions and the removal of contaminants by RNAse/pronase (Sigma) treatments.

Because all ras mutations in colorectal tumours occur in codons $12 / 13$ or $59 / 61$ of the $\mathrm{Ki}$-ras oncogene, these were the regions sequenced. These were amplified using the primers listed in table 1.

ras codon $12 / 13$

PCR products were generated using the following cycle: one minute at $95^{\circ} \mathrm{C}, 30$ seconds at $55^{\circ} \mathrm{C}$, one minute at $72^{\circ} \mathrm{C}$ for 32 cycles, and then five minutes at $72^{\circ} \mathrm{C}$. The $100 \mu \mathrm{l}$ reaction mixture was made up of the following: $10 \mu \mathrm{l}$ Taq buffer $(500 \mathrm{mM} \mathrm{KCl}, 100 \mathrm{mM}$ Tris/HCl (pH 9.0), 1\% Triton X-100) (Promega), $2.5 \mathrm{mM} \mathrm{MgCl}_{2}, 80 \mathrm{ng}$ DNA, $0.2 \mathrm{mM}$ of each dNTP, 50 pmoles of each primer, and 2.5 units of Taq polymerase (Promega).

ras codon 61

PCR products were generated using incubations for one minute at $95^{\circ} \mathrm{C}$, three minutes at $63^{\circ} \mathrm{C}$ for 32 cycles and then three minutes at $72^{\circ} \mathrm{C}$. The $100 \mu \mathrm{l}$ reaction mixture was made up of the following: $10 \mu \mathrm{l}$ Taq buffer $(500 \mathrm{mM} \mathrm{KCl}, 100 \mathrm{mM}$ Tris (pH 9.0), $1 \%$ Triton X-100), $100 \mathrm{ng}$ DNA, $0 \cdot 2 \mathrm{mM}$ of each dNTP, $2.5 \mathrm{mM} \mathrm{MgCl}_{2} 100$ pmoles of each primer, and 2.5 units of Taq polymerase. The PCR products were electrophoresed in Trisacetate/EDTA buffer, exised from the agarose gel and purified by "Mermaid clean" (Bio 101) (for purification of fragments less than 200 base pairs in length) or by electoelution.

PCR products were sequenced by an adaptation of the Sequenase method, using the Sequenase 2.0 Version sequencing kit (US Biochemical Corporation). The 12.1B primer was used to sequence the ras codon $12 / 13$, while the $61.1 \mathrm{~B}$ primer was used to sequence the ras codon 61. Once sequencing was completed, the sequence was visualised by electrophoresis through a pre-run $6 \%$ acrylamide denaturing gel. The gel was run at $80 \mathrm{~W}$ for approximately two hours, then soaked in $10 \%$ glacial acetic acid for 35 minutes and dried at $80^{\circ} \mathrm{C}$ before being exposed to Kodak $x$ ray film.

\section{EXPRESSION OF P21 $1^{\text {ras }}$}

The rat $\mathrm{IgG}_{1}$ monoclonal antibody Y13-259 recognising the $\mathrm{p} 21^{\text {ras }}$ protein encoded by the $\mathrm{Ki}$-ras oncogene was prepared by harvesting culture supernatant from the hybridoma cell line CRL1742. The saturation dilution of the antibody of 1 in 200 was estimated by titration with a ras transfected mouse cell line. The rat antibody used as an isotype matched control reagent for the Y13-259 antibody was produced as above from the R46A2 hybridoma cell line (from E A Havell, Trudeau Institute Inc., New York, USA). As p $21^{\text {ras }}$ is an internal protein, the staining procedure requires permeabilisation of the cells. Cells to be analysed were fixed in $2 \%$ paraformaldehyde in phosphate buffered saline (PBS) directly before use and incubated with
Table 2 Induction of class II antigen and ICAM-1 expression in colorectal cancer cell lines

\begin{tabular}{llll}
\hline Cell line & $\begin{array}{l}\text { Class II antigen } \\
\text { inducibility }^{\prime}\end{array}$ & $\begin{array}{l}\text { ICAM-1 } \\
\text { inducibility }\end{array}$ \\
\hline HT & $98 \cdot 1$ & $(+/-)$ & $8 \cdot 1$ \\
SW1417 & $78 \cdot 2$ & $(+)$ & $6 \cdot 2$ \\
Colo205 & $67 \cdot 5$ & $(+)$ & $3 \cdot 2$ \\
Colo201 & $11 \cdot 6$ & $(+/-)$ & $3 \cdot 3$ \\
HCT116 & $0 \rightarrow 40^{*}$ & $(-)$ & $0 \rightarrow 3 \cdot 9^{*}$ \\
SW1463 & $0 \rightarrow 21 \cdot 8^{*}$ & $(+)$ & $3 \cdot 7$ \\
LoVo & $2 \cdot 2$ & $(-)$ & $1 \cdot 5 \rightarrow 4^{*}$ \\
Caco-2 & $1 \cdot 3$ & $(++)$ & 0 \\
LS180 & 0 & $(+/-)$ & $0 \rightarrow 3 \cdot 2^{*}$ \\
\hline
\end{tabular}

${ }^{1}$ Inducibility is expressed as the ratio of the peak fluorescence of the induced cells to that of the uninduced cells - that is, the of the induced cells to that of the uninduced cells-that is, the fold induction of the antigen. Where heterogeneous staining was apparent-that is, a broad peak of fluorescence: see fig 1B indicated by ${ }^{*}$, the range of inducibility is given.

Bracketed arithmetic signs indicate, in a semiquantitative manner, the extent of uninduced expression of ICAM-1.

the primary antibody diluted in $0.1 \%$ Tween 20 and $0.25 \%$ saponin at $4^{\circ} \mathrm{C}$ for one hour, followed by incubations of the biotinylated secondary antibody (Amersham International, Little Chalfont, UK) diluted 1 in 200 in diluent $(0.1 \%$ Tween $20,0.25 \%$ saponin, $10 \mathrm{mg} / \mathrm{ml}$ bovine serum albumin) for one hour at $4^{\circ} \mathrm{C}$ and Streptavidin/phycoerythrin complex (Amersham International) diluted 1 in 50 in diluent at $4^{\circ} \mathrm{C}$ for 45 minutes. Prior to analysis the cells were resuspended in PBS.

\section{Results}

EXPRESSION OF CLASS II ANTIGENS AND ICAM-1 BY TUMOUR CELL LINES

It was apparent that there was great variation in the expression of both class II antigens and ICAM-1 after treatment with IFN- $\gamma$ and that the lines also showed heterogeneity of ICAM-1 expression in the absence of IFN- $\gamma$ treatment. However, as all of the lines were essentially negative for class II antigen expression in the absence of IFN- $\gamma$ treatment, it was possible to arrange the lines in order of inducibility for class II antigens: four lines (HT29, Colo205, SW 1417, and Colo201) were all strongly inducible (fluoresence intensity more than 10fold greater than without IFN- $\gamma$ ); LoVo was weakly inducible (less than twofold); two (Caco2 and LS180) did not show significant inducibility, whilst two other lines (HCT116 and SW1463) showed heterogeneity of expression after treatment with IFN- $\gamma$.

Because of the constitutive expression of ICAM-1 by some of the lines, it is impossible to give an unequivocal order for its inducibility. However, there did seem to be a rough correlation between expression of the two, as the four lines which showed the most class II antigen induction were also relatively strongly inducible for ICAM-1, while three weakly inducible for class II antigens were also weakly inducible for ICAM-1. Of the two lines heterogeneous for induction of class II antigen expression, one showed strong ICAM-1 induction and the other was heterogeneous.

These data for class II antigen and ICAM1 expression are summarised in table 2 . Figure 1 shows flow cytometry profiles for the induction of class II antigens and ICAM-1 by representative cell lines (Caco-2, HCT116 and 

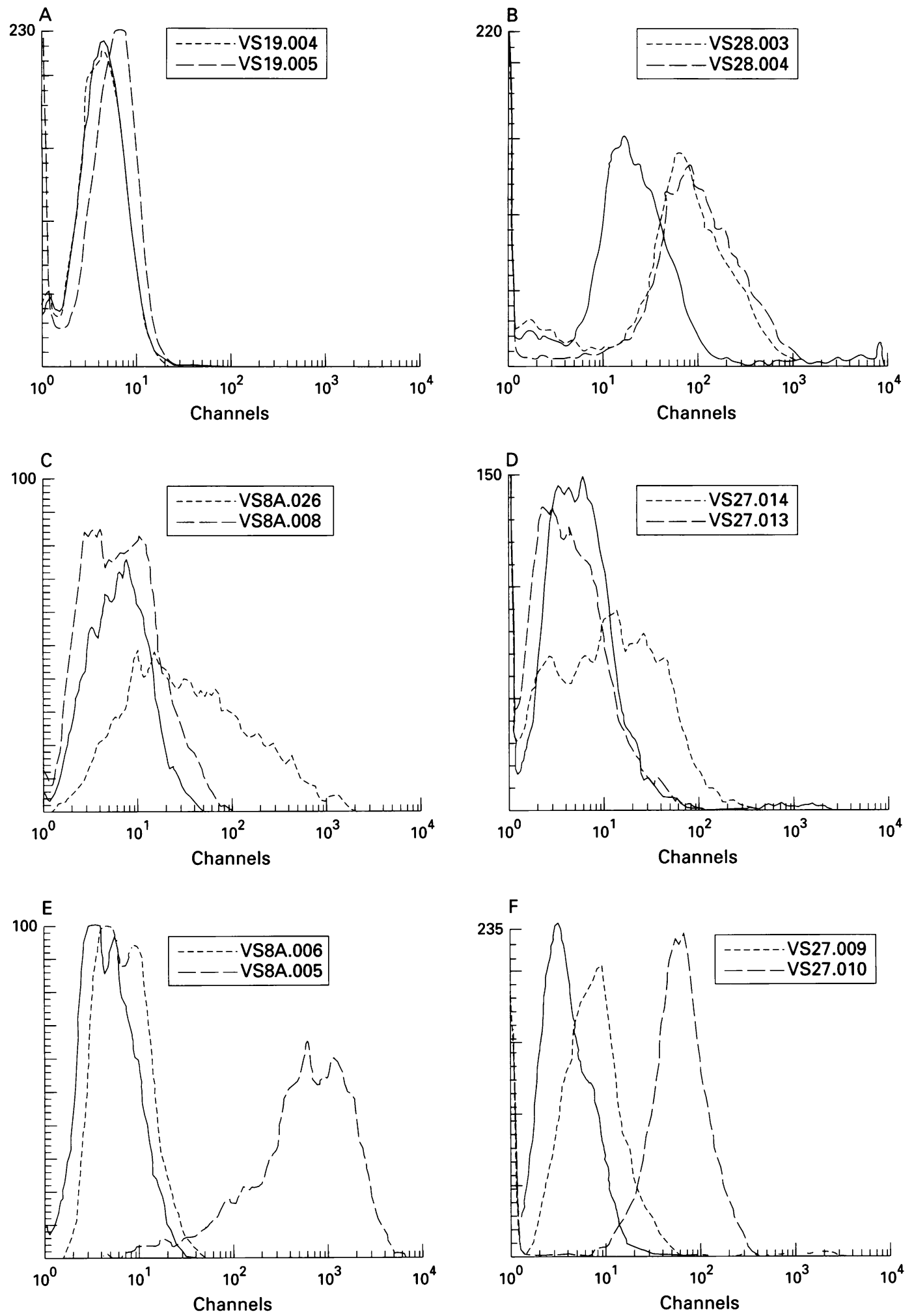

Figure 1 Induction of class II antigen and ICAM-1 expession in colorectal cell lines. In all graphs the solid profile represents the background staining with control antibody. $A, C$ and $E$, class II antigen staining; $B, D$ and $F, I C A M-1$ staining. (A) Caco-2 class II trace VS19004 without IFN- $\gamma$ and VS19005 with IFN- $\gamma ;$ (B) Caco-2 ICAM-1 trace

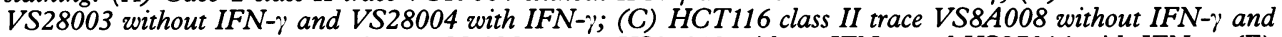

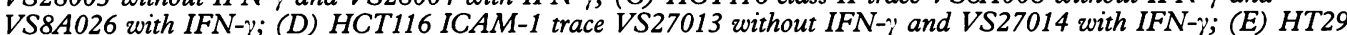

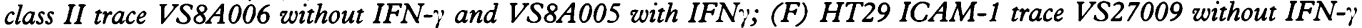
and VS27010 with IFN-i.

HT29) which show contrasting responses to IFN- $\gamma$.

The inducibility of class I antigens in the cell lines was checked as a control of sensitivity to IFN- $\gamma$ : all were inducible (data not shown). Non-enzymatic methods of cell removal were compared with those incorporating trypsin to ensure that the trypsin did not significantly alter the levels of the expression, which was found to be the case (data not shown). In order to check that failure to express class II antigens or ICAM-1 was not the result of insufficient 
Table 3 ras p21 expression in colorectal cancer cell lines

\begin{tabular}{lll}
\hline Cell line & $\begin{array}{l}\text { Class II antigen } \\
\text { inducibility rank }\end{array}$ & ras specific fluorescence \\
\hline Caco-2 & 8 & $705 \cdot 3$ \\
LoVo & 7 & $565 \cdot 95$ \\
SW1417 & 2 & $442 \cdot 45$ \\
HCT116 & $5(\mathrm{~m})^{2}$ & $313 \cdot 78$ \\
SW1463 & $6(\mathrm{~m})$ & $241 \cdot 16$ \\
LS180 & $9(\mathrm{~m})$ & $198 \cdot 13$ \\
HT29 & 1 & $158 \cdot 9$ \\
Colo205 & 3 & $49 \cdot 89$ \\
Colo201 & 4 & $44 \cdot 0$ \\
\hline
\end{tabular}

'As in table $2 ;{ }^{2} \mathrm{~m}$ indicates mutant ras; ${ }^{3}$ peak mean fluorescence with background fluorescence subtracted. that a few were inducible. In the latter class II antigen and ICAM-1 expression was induced in essentially all of the tumour cells. The data from 21 tumours are summarised in table 4.

The ras mutation status of these 21 tumours was determined by sequencing the Ki-ras gene. Of the 21 tumours, five harboured ras mutations, all of them in codon 12 (table 4). In all of these cases the normal base was also present, again suggesting heterozygosity. The corresponding normal colonic material collected

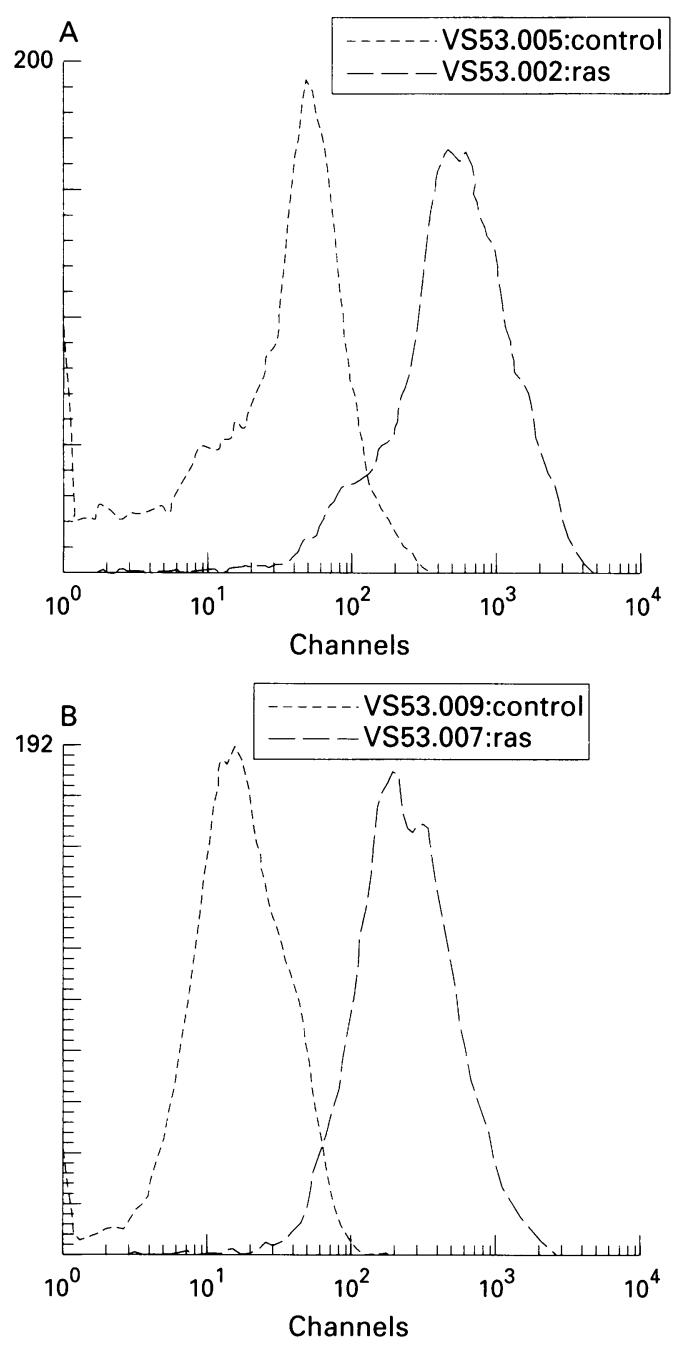

ACTIVATION OF ras IN TUMOUR CELL LINES The ras gene may be activated either by mutation or by overexpression of the gene. Accordingly, we have sequenced the Ki-ras gene and measured p2 $1^{\text {ras }}$ levels by immunofluorescence and flow cytometry in the cell lines described to determine their ras activation status.

Of the nine cell lines, three (HCT116, SW1463 and LS180) contained mutations in codons 12 or 13: these were HCT116 (codon 13: GGC $\rightarrow$ GAC); SW1463 (codon 12: GGT $\rightarrow$ TGT) and LS180 (codon 12: GGT $\rightarrow$ GAT). In the case of SW1463, the mutation was homogeneous (that is, no normal base was present), but in the other two cases there were normal bases present as well as mutant, indicating either heterozygosity or a mixed population. One of the lines (HCT116) showing heterogeneous class II antigen expression was sorted by fluorescence activated cell sorting to separate cells with high and low levels of expression. Of the sorted variants of HCT116, the non-class II expressing population seemed to contain the mutation, whilst the class II expressing population seemed to be normal. This suggests that the original population was a mixture of ras normal and mutant cells and it was the latter that failed to respond to IFN- $\gamma$.

The fluorescence data obtained for $\mathrm{p} 21^{\text {ras }}$ are summarised in table 3 and allowed us to order the cell lines according to the level of expression of the gene: Caco-2>LoVo>SW1417>HCT116> SW 1463>LS180>HT 29>Colo205>Colo201. Figure 2 shows representative flow cytometry profiles of $\mathrm{p} 21^{\text {ras }}$ expression by the cell lines HT29, HCT116 and Caco-2.

\section{INDUCTION OF COLORECTAL TUMOURS AND} ACTIVATION OF ras

We have previously reported on the induction of MHC class II antigen and ICAM-1 expression by IFN- $\gamma$ in tumour cells derived from colorectal carcinomas in primary culture. ${ }^{9}$ The extent of expression was determined by immunohistochemical techniques on cytospin preparations, identifying tumour cells by morphological criteria. The data indicated that most of the tumours could not be induced, but

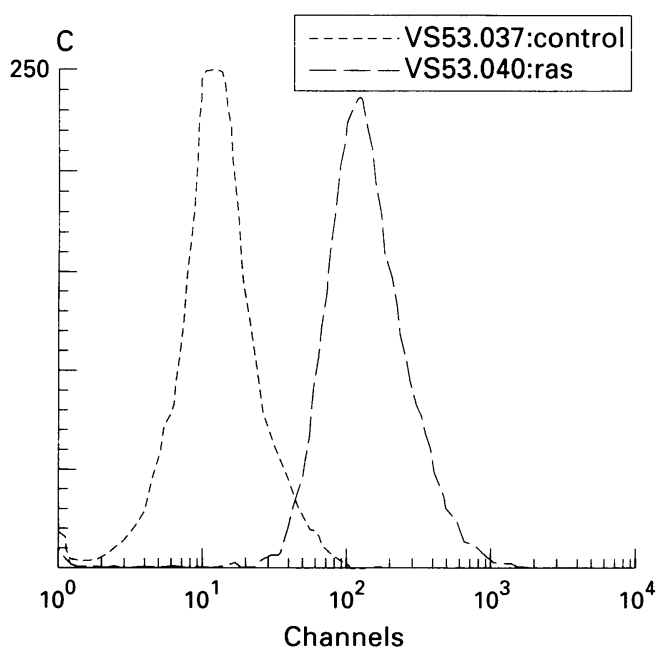

Figure 2 p2 $1^{\text {ras }}$ expression by colorectal cell lines. (A) Caco-2, (B) HCT116 and (C) HT29. 
Table 4 Class II MHC antigen and ICAM-1 inducibility and ras mutations in colorectal cancer cell lines

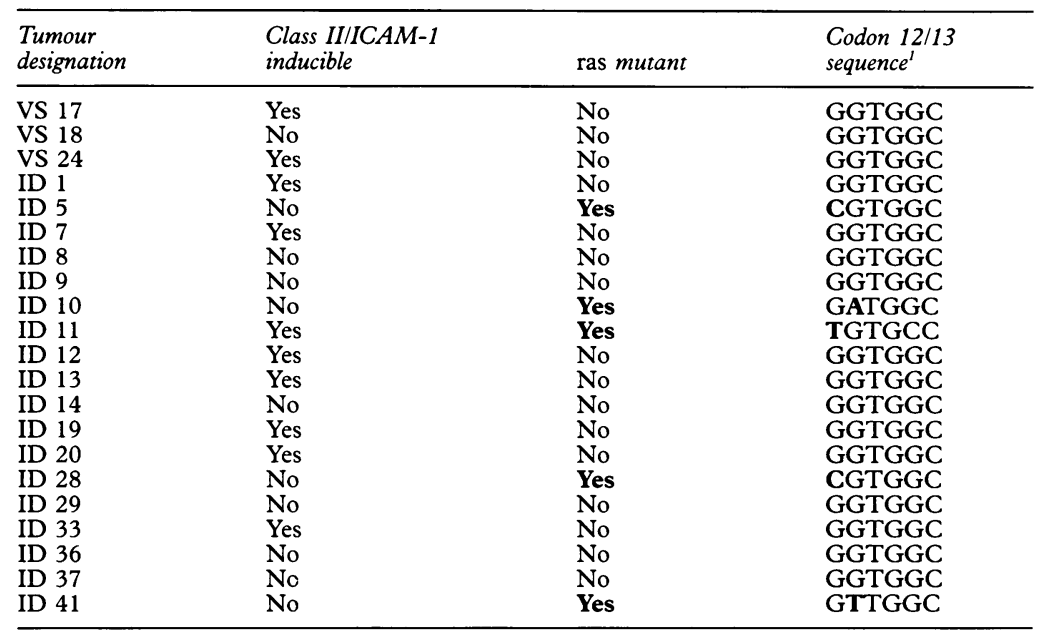

The mutant base is shown in bold. will be a one to one relation between ras activation and failure of class II antigen/ICAM-1 induction.

Inducibility of cells from the tumour ID11 containing the GGT $\rightarrow$ TGT mutation, replacing Gly with Cys, is not so easily explained. However, there is evidence that not all mutations in ras affect its functioning equally. In an extensive series of experiments Seeburg et $a l^{30}$ showed that the transforming ability of different codon 12 mutations varied with the amino acid substitution. It is also clear that codon 13 mutations affect the GTPase activity of $\mathrm{p} 21^{\text {ras }}$ less than do codon 12 mutations. ${ }^{31}$ More recently, work by Finkelstein et $a l^{32}$ with colorectal carcinoma has suggested that the nature of the mutations of the ras gene could influence the biological behaviour of the cancer. In this instance the finding was that the particular substitution correlated with the degree of cancer spread. In particular, tumours with a Gly $\rightarrow$ Val substitution were indolent whilst those with a Gly $\rightarrow$ Asp mutation were very aggressive. Similar results have been obtained in pancreatic carcinoma. ${ }^{33}$ It is therefore possible that the mutation occurring in ID11 (Gly $\rightarrow$ Val substitution at codon 12 ) which was IFN inducible was such that the IFN signalling pathway was less affected.

In summary, these data indicate that whilst ras activation may play a role in controlling responses to cytokines, clearly there are other important factors involved.

This work was supported by the Cancer Research Campaign.

\section{Discussion}

The response of tumours to cytokines is heterogeneous. We have investigated whether failure of tumour cells to respond to IFN- $\gamma$ is because of subversion of growth factor signalling pathways in the tumour cells, particularly through ras activation. This was because, as we have discussed earlier, there is evidence for "cross talk" between growth factor and cytokine pathways. We have studied colorectal tumours as our experimental system because some $40 \%$ of these exhibit ras activation.

Of the cell lines studied, the most inducible all harboured normal $\mathrm{Ki}$-ras genes and expressed low levels of $\mathrm{p} 21^{\text {ras }}$, suggesting that there is indeed a correlation between ras activation and inducibility. However, this cannot be shown to be statistically significant because of the difficulty in quantifying inducibility precisely in those cell lines where there was a range of expression. Of the 10 inducible tumours, with one exception, the ras gene was normal; of the 11 non-inducible tumours, four contained a mutant ras gene. However, $\chi^{2}$ analysis revealed that the correlation was not significant.

These data clearly do not unequivocally support the hypothesis. Non-inducibility of cells with normal ras can be explained by adducing other possible mechanisms for subversion of the IFN- $\gamma$ response, such as the inactivation of regulating proteins such as the GTPase activiating protein NF-1 or activation of other growth factor receptors/tyrosine kinases, etc., in what is a complex system of overlapping components. Therefore, it is unlikely that there

Andersen C, Ladefoged S, Larsen S. Acute kidney graft rejection - a morphological and immunohistological study on zero-hour and follow-up biopsies with special emphasis
on cellular infiltrates and adhesion molecules. APMIS 1994;102:23-37.

2 McDonald G, Jewell D. Class II antigen (HLA-DR) expression by intestinal epithelial cells in inflammatory diseases of the colon. 7 Clin Pathol 1987;40:312-17.

3 Tsomides T, Eisen H. T-cell antigens in cancer. Proc Natl Acad Sci USA 1994;91:3487-9.

4 Esteban F, Ruizcabello F, Concha A, Perezayala M, Sanchezrosas J, Garrido F. HLA-DR expression is associated with excellent prognosis in squamous cell carcinoma of the larynx. Clin Exp Metastasis 1990;8:319-28.

5 Brunner C, Gokel J, Riethmuller G, Johnson J. Expression of HLA-D subloci DR and DQ by breast carcinomas is correlated with distinct parameters of favourable prognosis. Eur f Cancer 1991;27:411-16.

6 Hilton D, West K. An evaluation of the prognostic significance of HLA-DR expression in gastric carcinoma. Cancer 1990;66:1154-7.

7 Norheim-Andersen S, Rognum T, Lund E, Meling G, Hauge S. Strong HLA-DR expression in large bowel carcinomas is associated with good prognosis. $\operatorname{Br} \mathcal{F}$ Cancer 1993;68:80-5.

8 Bateman W, Fiera R, Matthews N, Morris A. Inducibility of class II major histocompatibility complex antigens by interferon gamma is associated with reduced tumorigenicity in $\mathrm{C} 3 \mathrm{H}$ mouse fibroblasts transformed with $\mathrm{v}$ Ki-ras. F Exp Med 1990;173:193-6.

9 Ostrand-Rosenberg S, Thakur A, Clements V. Rejection of mouse sarcoma cells after transfection of class II genes. $\mathcal{F}$ Immunol 1990;144:4068-71.

10 Donnellan I, Cantrill J, Fraser I, Morris A. Activation by interferon- $\gamma$ of expression of ICAM-1 and MHC class Il antigens in tumour cells from colorectal carcinomas. $f$ Clin Pathol: Mol Pathol 1995;48:M40-5.

11 McCormick F. Activators and effectors of ras p21 proteins. Curr Opin Genet Dev 1994;4:71-6.

12 Bos J. Ras oncogenes in human cancer: A review. Cancer Res 1989;49:4682-9.

13 Darnell J, Kerr I, Stark G. Jak-STAT pathways and transcriptional activation in response to IFNs and other extracellular signaling proteins. Science 1994;264:1415-21.

14 Benveniste E, Vidovic M, Panek R, Norris J, Reddy A Benos D. Interferon gamma induced astrocyte class II Benos D. Interferon gamma induced astrocyte class 1 major histocompatibility antigen complex gene expression is associated with both protein kinase C activa 
15 Fan X, Goldberg M, Bloom B. Interferon gamma induced Proc Natl Acad Sci USA 1988;85:5122-5.

16 Liu M, Brownsey R, Reiner N. Gamma interferon induces rapid and coordinate activation of mitogen activated protein kinase $C$ in human monocytes. Infect Immun 1994; 62:2722-31.

17 Todd I, Hammond L, James R, Feldmann M, Bottazzo G Epidermal growth factor and transforming growth factor alpha suppress HLA class II induction in human thyroid alpha suppress HLA class II induction in

18 Lu Y, Ussery G, Muncaster M, Gallie B, Blanck G. Evidence for retinoblastoma protein $(\mathrm{RB})$ dependent and independent IFN-g responses: $\mathrm{RB}$ coordinately rescues IFN-g induction of MHC class II gene transcription in non-inducible breast carcinoma cells. Oncogene 1994;9:1015-19.

19 Hume C, Accolla R, Lee J. Defective HLA class II expression in a regulatory mutant is partially complemented by activated ras oncogenes. Proc Natl Acad Sci USA 1987;84: 8603-7.

20 Schrier P, Peltenburg L. Relationship between myc oncogene activation and MHC class I expression. Adv Cancer Res 1993;60:181-246.

21 Friedman D, Ricciardi R. Adenovirus type 12 E1A gene represses accumulation of MHC class I mRNAs at th evel of transcription. Virology 1988;165:303-5.

22 Darley R, Morris A. Sequential changes in MHC antigen expression induced by the v-Ki-ras oncogene. Cancer Immunol Immunother 1993;35:46-52.

23 Morris A, Ward G, Bateman W. Interaction of v-Ki-ras oncogene and interferon gamma in the control of histocompatibility antigen expression in mouse fibroblasts. Cell Immunol 1989;120:470-6.
24 Nishizuka Y. Intracellular signalling by hydrolysis of phospholipids and activation of protein kinase C. Science 1992; 258:607-14.

25 Marquardt B, Frith D, Stabel S. Signaling from TPA to MAP kinase requires protein kinase $C, R A F$ and MEK reconstitution of the signalling pathway in vitro. Oncogene 1994;9:3213-18.

26 Fu X-Y, Zhang J-J. Transcription factor $\mathrm{p} 91$ interacts with the epidermal growth factor receptor and mediates acthe epidermal growth factor receptor and mediates ac-
tivation of the c-fos gene promoter. Cell 1993;74:1135-45.

27 Ruff-Jamison S, Chen K, Cohen S. Induction by EGF and interferon gamma of tyrosine phosphorylated DNA binding proteins in mouse liver nuclei. Science 1993;261: 1733-6.

28 Sadowski H, Shuai K, Darnell J, Gilman M. A common nuclear signal transduction pathway activated by growth factor and cytokine receptors. Science 1993;261:1739-44.

29 Shuai K, Ziemiecki A, Wilks A, Harpur A, Sadowski H, Gilman $M$, et al. Polypeptide signalling to the nucleus through tyrosine phosphorylation of Jak and Stat proteins. Nature 1993;366:580-3.

30 Seeburg P, Colby W, Capon D, Goeddel D, Levinson A Biological properties of human c-Ha-ras 1 genes mutated

31 Barbacid M. Ras genes. Ann Rev Biochem 1987;56:779-827. 32 Finkelstein S, Sayegh R, Christensen S, Swalsky P. Genotypic classification of colorectal adenocarcinoma - biologic behavior correlates with K-ras-2 mutation type. Cancer 1993;71:3827-38.

33 Finkelstein S, Becich M, Przgodzki R, Sayegh R, Bakker A, Swalsky P. K-ras-2 genotyping of pancreatic adenocarcinoma - correlation with biological behavior [abstract]. Lab Invest 1994;70:A60. 